\title{
Activation Unproductive Coal Powder with Urea to Improve Chemical Properties of Ultisols
}

\author{
Herviyanti $^{\#}$, T. B. Prasetyo ${ }^{\#}$ Juniarti $^{\#}$, D. Rezki ${ }^{*}$ \\ \# Department of Soil Science, Faculty.of Agriculture, Andalas University Limau Manis Padang, 25163, Indonesia \\ E-mail:evi.64.faperta@gmail.com,Teguh160395@yahoo.com,yuni_soil@yahoo.co.id
}

* Department of plantation cultivation, Faculty of Agriculture, Andalas University Limau Manis Padang, 25163, Indonesia

E-mail:Dewirezki600@yahoo.co.id

\begin{abstract}
This study consisted of two stages of the experiment, in which the first phase was aimed to test the level of activity unproductive coal powder (sub-bituminous) activated with urea (CO(NH2)2). Experiment II was aimed to select the dose of Urea was right in fixing chemical properties sub-bituminous powder to be applied to mineral soil acidic (Ultisols). Experiment I form into activation powder sub-bituminous $(50 \mathrm{~g})$ with urea at a dose of $1,2,3,4,5,6,7,8,9$ and $10 \%$. The second experiment was shaped non-factorial consisting of 15 treatments combined with two replications. Combination treatments consisted of sub-bituminous Powder doses: 0.5 ; 1 ; and $1.5 \%$ by the weight of the soil and the dose activator defined based on the results of phase I trials of 0 ; 2.5 ; 5; 7.5 and $10 \%$ by weight of powder sub-bituminous. The results showed the higher amounts of activator used, the higher pH and CEC sub-bituminous Powder and increasing from emerging functional groups. The use of sub-bituminous Powder was activated with urea can improve some soil chemical properties such as increasing the $\mathrm{pH}$, available $\mathrm{P}$, organic-C, $\mathrm{CEC}$ and reducing $\mathrm{Al}$-exch of Ultisols.
\end{abstract}

Keywords - activator; chemical properties; sub-bituminous; urea; Ultisols

\section{INTRODUCTION}

The dryland sub optimal of soil which dominated mineral soil is Ultisols ( \pm 45.79 million ha) $(24.3 \%)$ of Indonesia's land at the spread in Sumatera, Kalimantan and Irian [1]. This mineral soil is less productive for growing crops and plantation because of the low productivity of land, acid soil reaction, and largest phosphorus (P) fixation. [2] said that Ultisols is ordo of land that forms in the tropics humid which had the process of weathering very advanced, the leaching of soil nutrients as well as a base to the bottom layer, while the oxides of $\mathrm{Al}$ and $\mathrm{Fe}$ as well as some metal oxides that are resistant to weathering lagging.

Efforts to address the problem of heavy metal poisoning ( $\mathrm{Al}$ and $\mathrm{Fe}$ ) and nutrient deficiencies, especially $\mathrm{P}$ can be done with the addition of organic matter to the soil. But the organic material that is often used as manure, green manure, and compost that requires a long weathering process not enough to be able to react in the soil. Through this research used components of organic material that faster reaction, the most active in the ground with electric charge and the cation exchange capacity (CEC) of greater than clay mineral is humic material (humic acid + fulvic acid). According [3] humic acid (HA) addition increased electrical conductivity values during all incubation periods. HA applications decreased soil modulus of rupture. Application of HA at the rate of $4 \%$ significantly increased soil organic carbon contents. HA applications at the rate of $4 \%$ significantly increased both mean soil total nitrogen content and aggregate stability after three incubation periods. Therefore, HA has the potential to improve the structure of soil in the short term.

The humic material can be found in various environments such as soils, natural waters, rivers, lakes, sea sediment plants, peat, and composts. However, none of these resources are as abundant as low-grade coal (sub-bituminous or lignite). The low-grade coal recorded $40-85 \%$ of humic substances compare to black peat, $10-40 \%$; sapropel peat, $10-20 \%$; brown coal, $10-30 \%$, compost, $2-5 \%$, soil and sludge, $1-5 \%$ [4]. Ref. [5], reported that the humic material capable extracted from sub-bituminous derived from Bonjol Pasaman only reached $31.5 \%$.

Sub-bituminous have a lower energy content (4000-6000 $\mathrm{kcal} / \mathrm{kg}$ ). Thus the low-rank coal that is not productive as an 
energy source can be treated as an alternative source of organic matter to improve soil productivity of Ultisol.

Lignite is commonly used as an organic amendment in soil restoration, too. Experiments suggest that prior dispersion may enhance the stabilizing effect on soil structure. Application in aqueous ammonium might be a suitable mean of adding a humic acid fraction to artificial top soils. Increasing stability was only observed for materials already containing a clay mineral fraction [6].

The use of humic material components of sub-bituminous derived from Bonjol Pasaman of the [7] can improve the efficiency of $\mathrm{P}$ fertilization and productivity of marginal lands for corn and rice planted. After compared with compost turned out to have the same capabilities, while the amount of sub-bituminous required only one-third of the amount of compost as humic matter content of subbituminous is higher than compost $(31.5 \%$ compared to $11 \%$ ). Low-rank coals are usually used for the production of humic acids, which are in the form of alkali-soluble humate salts [8].

The humic material can be obtained using the alkaline solvent. Ref. [9] and [10], stating that the solvents $\mathrm{NaOH}$ and $\mathrm{Na}_{2} \mathrm{CO}_{3}$ with a concentration of 0.1 to $0.5 \mathrm{~N}$ can be used to dissolve humic materials. Other solvents are also alkaline, which constitute the macro fertilizer was commonly used by farmers as urea. Urea is fully water soluble and made alkaline conditions with $\mathrm{pH}$ above 8.3 [11]. The using of urea will obtain humic material containing fertilizer, so it is more efficient in the application of organic materials and inorganic fertilizers on Ultisol. Nitrogen-rich coal humic acids are valuable fertilizers acting as growth stimulators. They improve plant resistance under unfavorable conditions, accelerate ripening and influence favorably biochemical processes during plant growth [12].

According to Ref. [12], urea solution by creating the alkaline conditions can extract of humic acid. Solution to urea $0.5 \mathrm{M}$, among the used concentrations, had the maximum yield of extraction. Among the measured characteristics extracted humic acid with urea had more functional groups, aliphatic structures and the great degree of saturation; in the other hand extracted humic acid with urea had a small size, but in general, was not large differences between the characteristics of the extracted humic acid with various concentrations. Finally, more research on the Urea as a new extract could be recommended. While [13] state that Nitrohumic acids, produced from base extraction of coals and peats oxidized with nitric acid, have received considerable attention as soil amendments in agriculture

Humic materials from sub-bituminous have nondegradable properties (relatively resistant) to the destruction of biological and chemical up to 10-50 years [2]. Therefore, the provision of humic materials into the soil is efficient because it can be used for several planting seasons and has a residual effect so that agriculture and plantations become more economical. Besides that, a problem often scarce supply of fertilizers can also be addressed by improving the efficiency of its use by mixing with unproductive coal powdered dominant containing humic materials. Ref, [14] reported that urea, $\mathrm{KCl}$, and $\mathrm{NaCl}$ could dissolve the powder sub-bituminous and produce humic materials, where Urea has a higher capacity than the $\mathrm{KCl}$ and $\mathrm{NaCl}$. Solubility tested sub-bituminous powdered with solvent urea can match the results of $\mathrm{NaOH}$ solvent commonly used for dissolving the humic material. How the activities and capabilities of this sub-bituminous powder that is activated by urea in improving chemical properties of Ultisol at Dharmasraya, West Sumatra unknown, so it needs to be examined. Mixing sub-bituminous powdered with ingredients was expected to dissolve humic materials without the need first to be extracted.

The purpose of this research was to prove that the urea as activator capable increasing the $\mathrm{pH}$ and CEC of subbituminous powdered. Besides, it also aims to study the ability of sub-bituminous powdered that has been activated in improving chemical properties of Ultisols.

\section{MATERIALS AND METHOD}

\section{A. The Experiments Incubation of Sub-Bituminous Powder with the Activator of Urea}

The purpose of the experiment was to test the level of activity of coal powder is not productive with Urea. Unproductive coal was taken from the District Bonjol Pasaman, West Sumatra at a depth of 1-2 meters from the ground. This type of coal based on the results of preliminary experiments was sub-bituminous [5], then cleaned, smoothed with hummer mills and sieved with a sieve of $125 \mu \mathrm{m}$, to obtain powdered sub-bituminous to be used as a treatment.

Sub-bituminous (50 g) was mixed with urea at a dose of 1 , $2,3,4,5,6,7,8,9$, and $10 \%$ by weight of powdered subbituminous, incubated for 10 days, and then the sample is taken for analysis. The parameters measured were $\mathrm{pH}$ of the mixture by electrometric, cation exchange capacity (CEC) with the washing method with ammonium acetate $\mathrm{pH} 7$, and the functional group is observed with Fourier Transform Infra Red (FTIR).

\section{B. The Experiments Incubation of Sub-Bituminous Powder with an Activator of Urea at Ultisols.}

This experiment was aimed to select the dose of Urea is right in fixing chemical properties of sub-bituminous powder to be applied to mineral soil acidic (Ultisols). The design used was nonfactorial with 15 treatment combinations of Completely Randomized Design (CRD) with two replications. Treatment combination consisted of dose subbituminous powder comprised of three levels, i.e., 0.5; 1 ; and $1.5 \%$ of the weight of the soil and the dose activator defined based on the results of phase I trials of $0 ; 2.5 ; 5 ; 7.5$ and $10 \%$ by weight of powdered sub-bituminous.

Soil types Ultisol taken in Kenagarian Gunung Selasih, Pulau Punjung Dharmasraya District of West Sumatera at a depth of $0-20 \mathrm{~cm}$ of the soil surface with composited method. Soil samples were dried, crushed, sieved with a $2 \mathrm{~mm}$ and mixed perfectly. After that, it was determined the water content of the soil. Soil sample that had been prepared weighed $500 \mathrm{~g}$ into the pot experiment thus treated subbituminous powder mixed with various ingredients, following the treatment that has been designed, incubation ten days. Then the soil samples were taken after incubation for analysis. 
The observations made in each experimental unit are the content of soil organic-C using the method of Walkley and Black, CEC using the method of leaching with $\mathrm{NH}_{4} \mathrm{OAc} \mathrm{pH}$ 7, exch-Al with $1 \mathrm{~N} \mathrm{KCl}$ method, determination of available$\mathrm{P}$ by the method of Bray II and the determination of $\mathrm{pH}$ by the potentiometric method.

\section{RESULTS AND DISCUSSION}

\section{A. Experiment I}

\section{1) $\mathrm{pH}$ and CEC of Sub-Bituminous Powder}

$\mathrm{pH}$ and CEC value of sub-bituminous powder activated with urea, are presented in Table 1. Based on Table 1. that the higher the dose of activator, the higher $\mathrm{pH}$ value of the soil. An increase in soil $\mathrm{pH}$ was caused urea is an alkaline solvent which can contribute $\mathrm{OH}^{-}$. Urea which is hydrolyzed to form ammonia and carbonate acid. Ammonia is not stable and can hydrolyze into ammonium and $\mathrm{OH}^{-}$[15]. The presence of $\mathrm{OH}^{-}$that causes the $\mathrm{pH}$ of sub-bituminous to increase [16]. If the ammonia compounds reacted with water to form ammonium hydroxide as a reaction and the following:

$$
\begin{aligned}
\mathrm{CO}\left(\mathrm{NH}_{2}\right)_{2}+2 \mathrm{H}_{2} \mathrm{O} & \longrightarrow 2 \mathrm{NH}_{3}+\mathrm{H}_{2} \mathrm{CO}_{3} \\
\mathrm{NH}_{3}+\mathrm{H}_{2} \mathrm{O} & \longrightarrow \mathrm{NH}_{4}^{+}+\mathrm{OH}^{-}
\end{aligned}
$$

TABLE I

THE PH AND CEC VALUE OF SUB-BITUMINOUS POWDER ACTIVATED WITH UREA

\begin{tabular}{|c|c|c|}
\hline $\begin{array}{c}\text { The dose } \\
\text { activator (\%) }\end{array}$ & pH & $\begin{array}{c}\text { CEC } \\
\left(\mathbf{m e}(\mathbf{1 0 0} \mathbf{~ g})^{-\mathbf{1}}\right)\end{array}$ \\
\hline 0 & 5.34 & 24.39 \\
\hline 1 & 7.22 & 54.26 \\
\hline 2 & 7.29 & 59.13 \\
\hline 3 & 8.30 & 71.68 \\
\hline 4 & 9.03 & 82.54 \\
\hline 5 & 9.07 & 93.47 \\
\hline 6 & 9.13 & 97.58 \\
\hline 7 & 9.24 & 113.54 \\
\hline 8 & 9.20 & 117.87 \\
\hline 9 & 8.68 & 123.79 \\
\hline 10 & 9.11 & 129.05 \\
\hline
\end{tabular}

Based on Table 1 it can be seen that the administration of urea with a concentration of $1-10 \%$, could be increased the CEC of sub-bituminous powder is high enough that each of 24.39 to $129.05 \mathrm{me}(100 \mathrm{~g})^{-1}$. Increased CEC values subbituminous powder activated with this compound resulting a functional group of sub-bituminous Powder mentioned more exposed due to the $\mathrm{pH}$ of the mixture of sub-bituminous Powder is much higher when compared with to activating. In the powder which has been active sub-bituminous are organic acids containing functional groups. Dissociation of these groups would be produced a negative charge that much so increased the CEC of sub-bituminous Powder. According to [2], electronegative colloid humus per unit weights to become larger than the clay silicate at neutral to alkaline $\mathrm{pH}$ conditions, because at that $\mathrm{pH}, \mathrm{H}^{+}$adsorbed will be exchanged with $\mathrm{Ca}, \mathrm{Mg}$ and other cations.

According to Ref. [17], the yield of humic acids was increased with the concentration of the alkaline solution. An increase in surface tension with the concentration of alkali, which indicated that humic solute was more anionic and therefore hydrophilic at higher molarity.

2) The Results of FTIR Analysis of Powder SubBituminous

The results of the IR spectroscopic sub-bituminous Powder (control) and sub-bituminous were activated with urea in the dose of $1-10 \%$ was presented in Fig. 1 and 2. Based on these figures it was seen that only sub-bituminous powder and which was activated both have some major wave numbers peak absorption band at $3350-3360 \mathrm{~cm}^{-1}$ which were a series of $\mathrm{O}-\mathrm{H}$ and $\mathrm{N}-\mathrm{H}$, wave number $1650 \mathrm{~cm}^{-1}$ there is ribbons circuit identifier $\mathrm{C}=\mathrm{O}$ and wave number of $1000 \mathrm{~cm}^{-1}$, which was usually the area of wave numbers ethyl group, $-\mathrm{CH}=\mathrm{CH}_{2}$, vinyl, aromatic aldehydes, amines and SH. While in Fig. 2, the use of urea as an activator could also bring up the absorption band rather strong at wave number $1446 \mathrm{~cm}^{-1}$ which were the identifier of the series $\mathrm{CH}$ of a methyl group and at wave number $1396 \mathrm{~cm}^{-1}$ which were an identifier of a series antisymmetric COO [9] and [10]. The greater the amount of urea were used the stronger absorption of the wave numbers, while the wave numbers around it are very weak absorption in sub-bituminous Powder only. Based on Fig. 2 can also be seen that the higher the amount of urea was added the stronger the absorption band at wavenumber $1446 \mathrm{~cm}^{-1}$, the stronger absorption band circuit antisymmetric COO-.

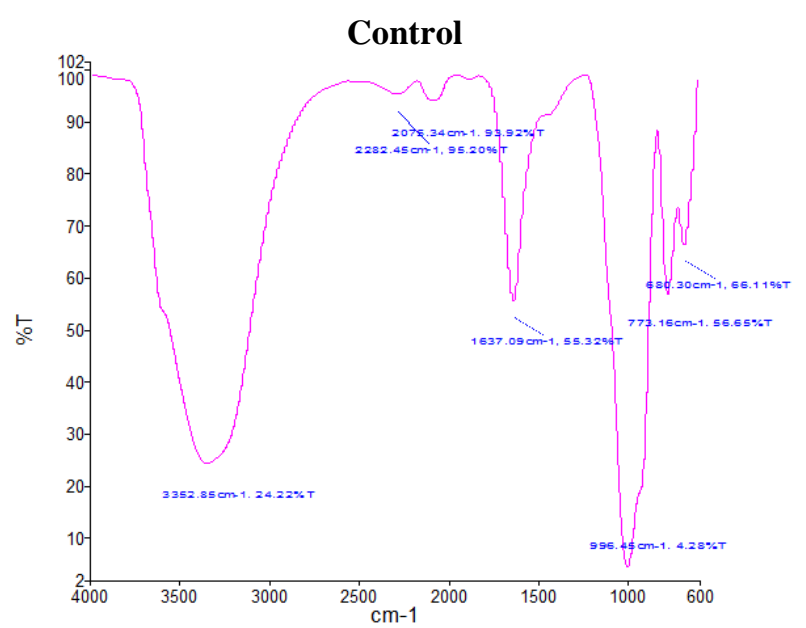

Fig. 1 Characterization of functional groups pulverized sub-bituminous

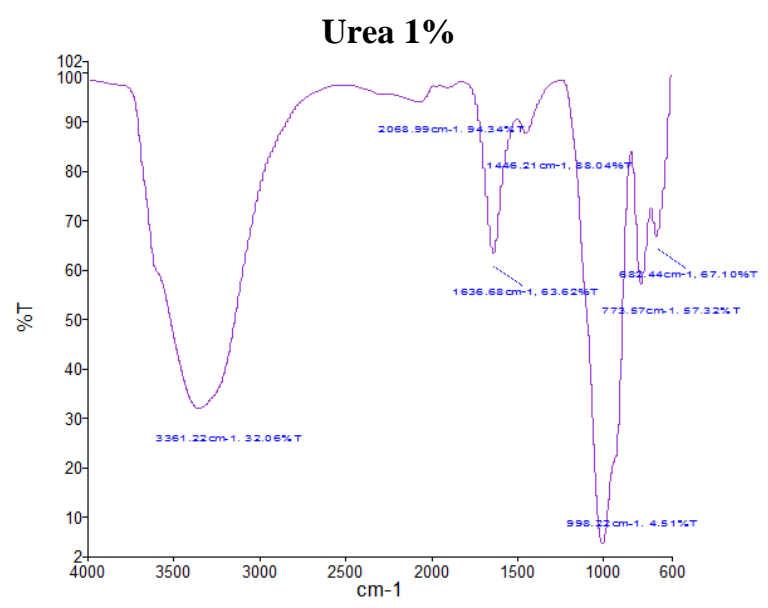



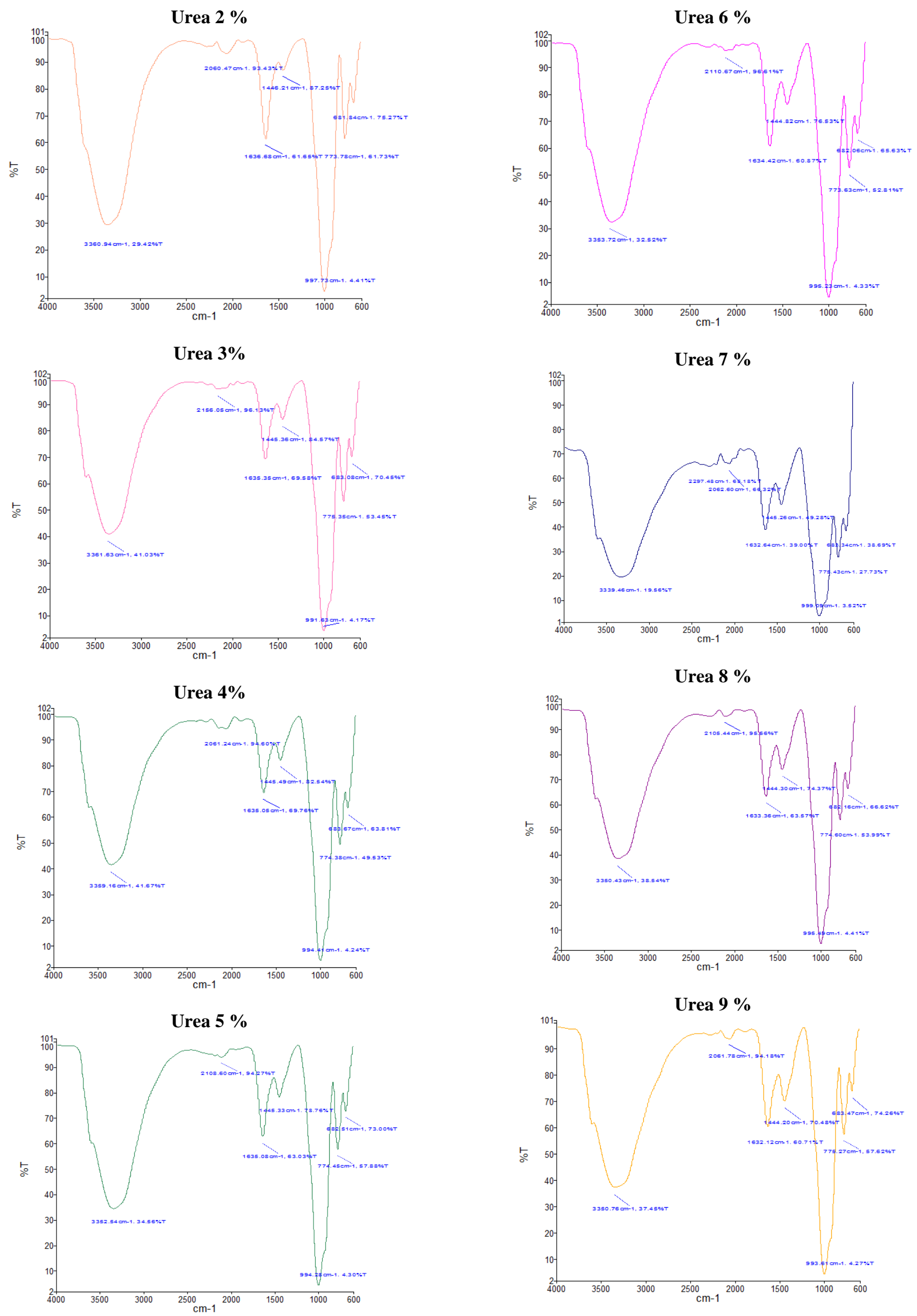


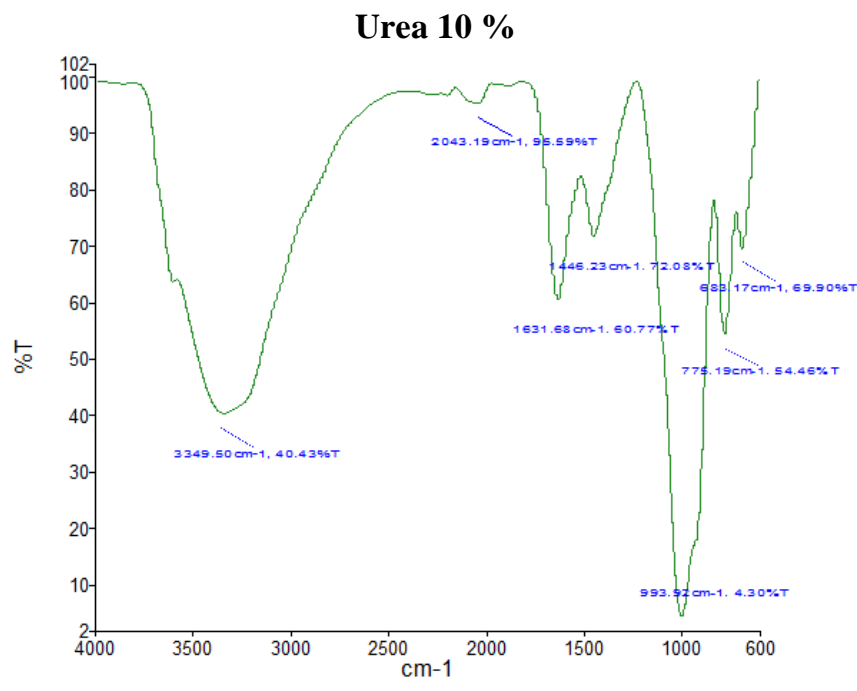

Fig. 2 Characterization of functional groups of sub-bituminous powder which are activated with Urea $1-10 \%$ by weight of sub-bituminous powder

While Ref. [17] reported that the important features of the spectra of the isolated humic acids exhibited similar absorption bands as reported elsewhere are: i) a weak sharp band at $3690 \mathrm{~cm}^{-1}$ which is attributed to the valence vibration of water; ii) a broadband around $3400 \mathrm{~cm}^{-1}$ due to $\mathrm{O}-\mathrm{H}$ stretching of phenol and alcohol; iii) a couple of weak bands between 2920 and $2850 \mathrm{~cm}^{-1}$ attributed to $\mathrm{C}-\mathrm{H}$ aliphatic; iv) a well-defined band at $1706 \mathrm{~cm}^{-1}$ due to $\mathrm{C}=\mathrm{O}$ stretching of ketonic and carboxylic groups; v) a strong peak at $1620 \mathrm{~cm}^{-1}$ assigned to aromatic $\mathrm{C}=\mathrm{C}$ stretching, $\mathrm{C}=\mathrm{O}$ of conjugated ketones and carboxylate ions; vi) a couple of peaks at 1430 $\mathrm{cm}^{-1}$ and $1334 \mathrm{~cm}^{-1}$ due to $\mathrm{C}-\mathrm{H}$ stretching; vii) a group of low intensity bands between $1000 \mathrm{~cm}^{-1}$ and $1100 \mathrm{~cm}^{-1}$ attributed to $\mathrm{Si}-\mathrm{O}$ stretching and $\mathrm{C}-\mathrm{O}$ stretching of polysaccharides; viii) weak bands at $1040 \mathrm{~cm}-1$ due to $\mathrm{S}=\mathrm{O}$ due to treatment of humic acids with sulphuric acids and ix) absorption bands at $470-480 \mathrm{~cm}^{-1}$ and $530-540 \mathrm{~cm}^{-1}$, which are due to mineral components.

The IR spectra of the humic acid extracted from coal A, B, leonardite and chrysanthemum compost revealed that typical major structural elements of humic acid such as H-bonded $\mathrm{OH}$ and $\mathrm{C}=\mathrm{O}$ (both carboxyl and ketonic) functional groups, $\mathrm{C}=\mathrm{C}$ in aromatic rings and aliphatic $\mathrm{CH}_{2}$ and $\mathrm{CH}_{3}$ groups were present indicating that the extracted humic acid was authentic [16].

\section{B. Experiment II}

The analysis of $\mathrm{pH}, \mathrm{Al}$-exch, P-available, CEC, and organic-C of Ultisols was treated with sub-bituminous powder activated with urea was presented in Fig. 3; 4; 5; 6; and 7. Fig 3 and 4 showed that the provision of subbituminous powder at doses of $0.5 ; 1.0$; and $1.5 \%$ by the weight of soil which was activated with the amount of urea could be increased the $\mathrm{pH}$ value and decreased $\mathrm{Al}$-exch of the soil. $\mathrm{pH}$ increased and $\mathrm{Al}$-exch decreased is due to higher amounts of sub-bituminous Powder that have been activated with urea the more functional groups $\mathrm{COOH}$ and $\mathrm{OH}$ (Fig. 2) are exposed and can bind $\mathrm{Al}^{3+}$ so as to increased the $\mathrm{pH}$ and availability of $\mathrm{P}$ in soil. This is the opinion of Ref. [9], which explains that the organic matter will generate organic anions can decrease from Al to form complex compounds so that the concentration of $\mathrm{Al}$ was reduced resulting in soil acidity lessened so that the soil $\mathrm{pH}$ was increased.

Ref [18] was confirmed that lignite, as a young coal type, contains a relatively high amount of humic acids and can be used for the low-cost production of these valuable substances. It was found that their adsorption efficiency is very high, usually between 80 and $100 \%$. Lignitic humic acids are suitable adsorbent for heavy metals and can also be used for cleaning of waters, soils, and other systems with low or residual concentrations of metal ions. Besides that [19] reported the use of alkaline Coal Fly ash (CFA) might offer an alternative way of metal-contaminated soil remediation/management via their immobilization.

The decreased of Al-exch would reduce of P-fixation by $\mathrm{Al}$, so $\mathrm{P}$ available in the soil was increased. [20] explains that the addition of organic acids in the soil occurred complex or chelate reaction with $\mathrm{Al}^{3+}$. Clay mineral complex formation of humic acids (components of humic materials) could be decreased P sorption of clay minerals. Furthermore, [7] and [20] explains that the availability of P in the soil can be improved by the addition of organic materials that will reduce $\mathrm{P}$ sorption as humic acid and fulvic acid works to protect sesquioxide by blocking the sides of the exchange. Following [9] explains that humic acid and fulvic acid can improve the solubility of liberation and insoluble inorganic $\mathrm{P}$ through a chelate process

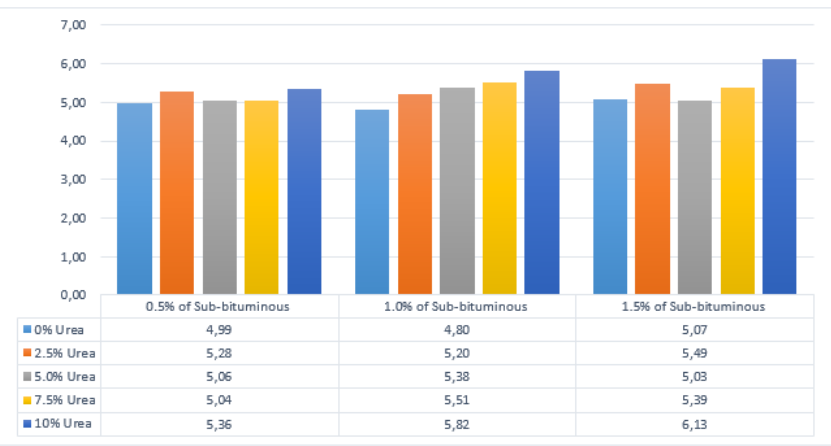

Fig 3 Effect of sub-bituminous powder activated with urea on $\mathrm{pH}$ of Ultis.ols after incubation 10 days

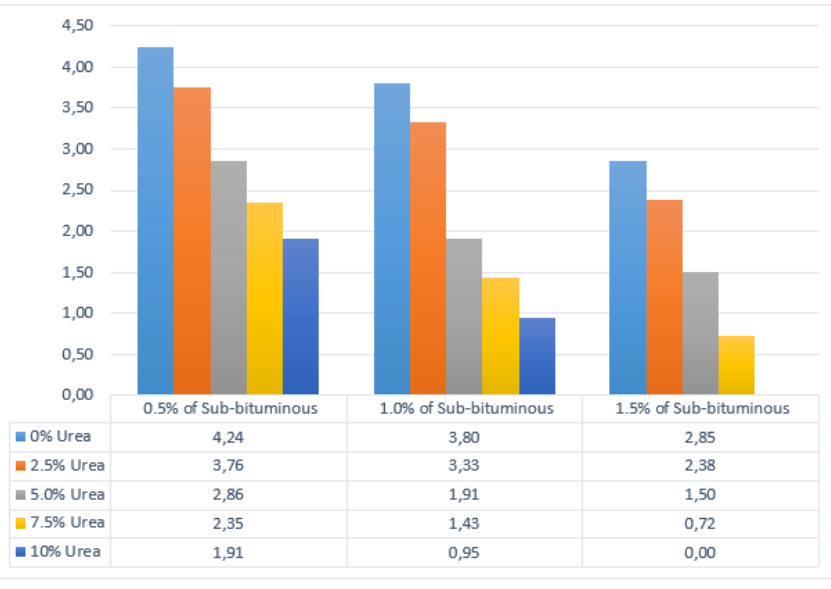

Fig. 4 Effect of sub-bituminous powder activated with urea on Al-exch of Ultisols, after incubation 10 days 


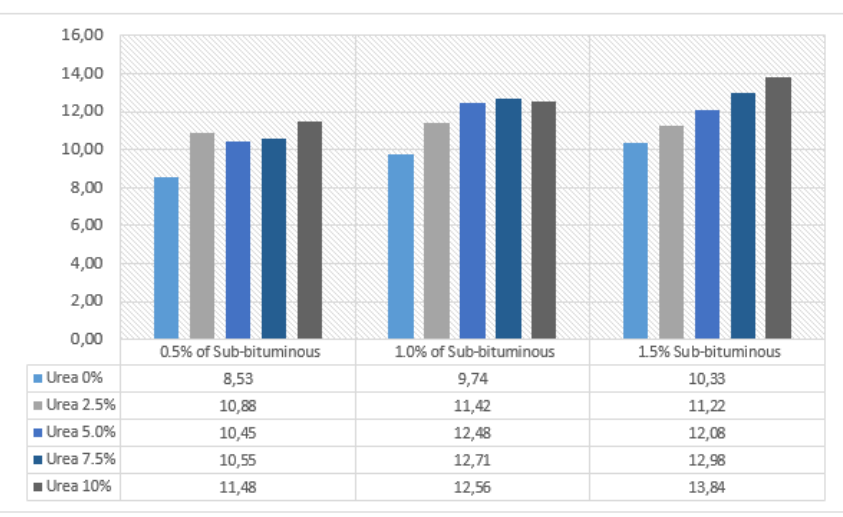

Fig. 5 Effect of sub-bituminous powder activated with urea on available-P of Ultisols, after incubation 10 days

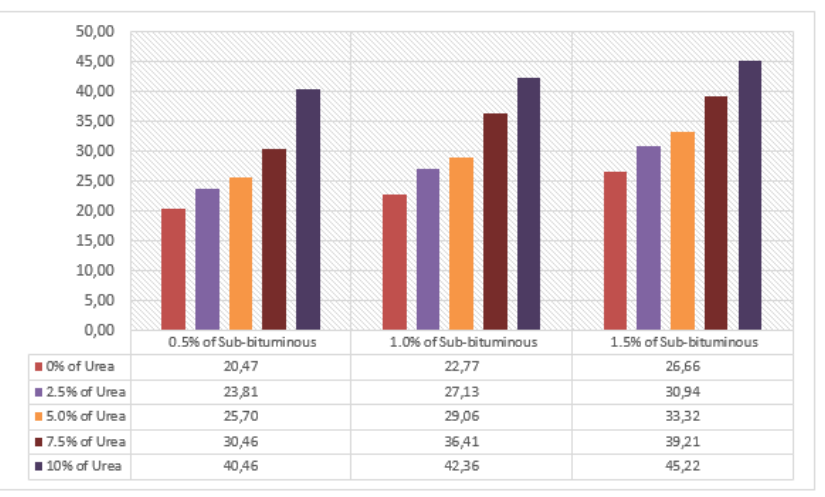

Fig. 6 Effect of sub-bituminous powder activated with urea on CEC of Ultisols, after incubation ten days

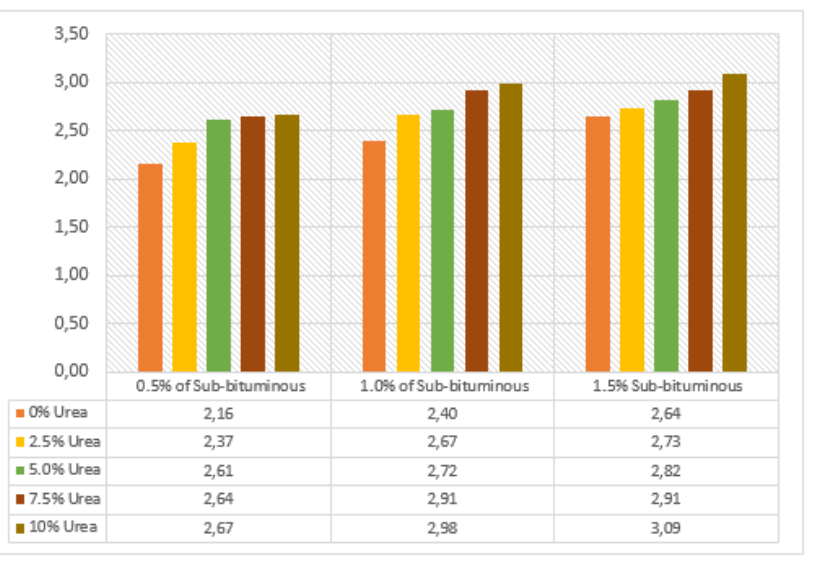

Fig. 7 Effect of sub-bituminous powder activated with urea on organic-C of Ultisols, after incubation 10 days

The provision of sub-bituminous powder at doses of 0.5 ; 1.0 ; and $1,5 \%$ by the weight of soil which was activated by urea with greater doses were increased soil CEC (Fig. 6). The higher dose of sub-bituminous Powder was given it will be many organic acids that can be used as a source of negative charge, so the value of soil CEC increased. It is appropriately described by Ref. [21] that the decomposition of organic matter will produce organic acids that can increase the negative charge through dissociation of the carboxyl group (COO). [6] and [22] also states that humic acid has a cation exchange capacity of 300-400 me $100 \mathrm{~g}^{-1}$. Thus, through the use of sub-bituminous Powder containing humic materials were increased the ability of soil to adsorb and exchange base cations.

Based on Fig. 7 it can also be seen that the provision of sub-bituminous powder at doses of $0.5 ; 1,0$; and $1.5 \%$ by the weight of soil which was activated by ingredient. When the amount of urea was increased, the content of soil organic $\mathrm{C}$ was higher. This increase is due to higher amounts of Urea ingredients, then the contribution to C-organic ingredients also high. Likewise with higher amounts of sub-bituminous Powder that has been activated with urea the more C-organic donations. This is because the sub-bituminous Powder contains organic-C > 30\%, while [24] reported humic acid from Ilgin Lignite (IL-HA) contains organic-C $65.31 \%$. [20] reported that humic acids were in many types of research as an excellent natural and organic way to provide plants and soil with a concentrated dose of essential nutrients, vitamins, and trace elements. The addition of humic substances extracted from an oxidized coal to soil was found to retard the onset of runoff process under rainfall. Furthermore, an increase of soil cation exchange capacity, $\mathrm{pH}$, and organic matter was observed after incorporation of coal-derived humic acids on two Nigerian nutrient poor tropical soils.

\section{CONCLUSIONS}

Our research concluded that the higher amounts of activator (urea) were used, the higher the $\mathrm{pH}$ and CEC subbituminous powder and increasing from emerging functional groups. The use of sub-bituminous powder was activated with urea improved some soil chemical properties such as increasing the $\mathrm{pH}$, available of $\mathrm{P}, \mathrm{CEC}$, organic-C, and reducing Al-exch of Ultisols.

\section{ACKNOWLEDGMENT}

We would like to thank the Rector and Chairman of the Institute for Research and Community Service of Andalas University Padang, the Ministry of Research Technology and the Higher Education Republic of Indonesia, the financial support of this research through research grants cluster professor of the fiscal year 2016.

\section{REFERENCES}

[1] Pusat Penelitian dan Pengembangan Tanah dan Agroklimat. Sumber Daya Lahan Indonesia dan Pengelolaannya. Badan Penelitian dan Pengembangan Pertanian Departemen Pertanian. 242 hal. 2004

[2] Brady, N.C., R.R. Weil. The nature and properties of soils. Twelfth Edition Prentice Hall. Upper Saddle River, New Jersey. 07458, 881 p. 1999.

[3] I. Gümü s and C. Seker. Influence of humic acid applications on modulus of rupture, aggregate stability, electrical conductivity, carbon and nitrogen content of a crusting problem soil. Solid Earth, 6, 1231-1236, 2015

[4] Sim Siong Fong, Lau Seng, Wong Nan Chong, Janice Asing, Muhammad Faizal b Md Nor, Amira Satirawaty bt Mohd Pauzan. Characterization of the coal derived humic acids from Mukah, Sarawak as soil conditioner. J. Braz. Chem. Soc. vol.17 no.3 São Paulo May/June. 2006

[5] Ahmad, F., Herviyanti, Gusnidar, dan Reski. Ekstraksi bahan humat dari batubara muda dengan menggunakan 10 jenis pelarut. Jurnal Solum. Vol 3 No. 2. Juli 2006.

[6] Whiteley, G.M. Effects of colloidal lignite on the stability of soil aggregates. Soil Technol., 6, p. 321-327. 1993.

[7] Herviyanti, F. Ahmad, Gusnidar, and A. Saidi. Potensi batubara tidak produktif sebagai sumber bahan organik alternatif untuk meningkatkan efisiensi pemupukan Fosfor dan produksi jagung pada 
tanah marjinal. Laporan Penelitian Hibah Kompetitif Sesuai Prioritas Nasional Batch II. 77 p. 2009.

[8] Yildirim, M., 鷊 Ozbayo 藝 Glu, G.: Production of ammonium itrohumate from Elbistan lignite and its use as a coal binder. Fuel, 76, p. 385-389. 1997.

[9] Stevenson, F. J. Humus chemistry, genesis, composition, reactions A Wiley-Interscience \& Sons. New York. 496 p. 1994.

[10] Tan, K. H. Principles of soil chemistry. Fourth Edition Revised and Expanded Marcel Dekker, Inc. New York. 362 p. 2011.

[11] Yagodin BA. . Agricultural Chemistry 1. Tanslated Version. MirPublishers. Moscow. p 375. 1984

[12] Hemati A., H. A. Alikhani, G. B. Marandi, L. Mohammadi Assessment The Possibility Of Humic Acid Extraction From Vermicompost With Urea. International Journal of Agriculture: Research and Review. 2 (6) : 705-709. 2012.

[13] Kevin A. Thorn*, Larry G. Cox. Nitrosation and Nitration of Fulvic Acid, Peat and Coal with Nitric Acid. Plos One| DOI:10.1371/journal.pone.0154981 May 13, 2016

[14] Herviyanti, T. B. Prasetyo, M. Harianti, A. Saidi. and Ismon L. Potency of humate material from subbituminous and how to do Incubation with Fosfor-Fertilizer to Increase Upland Rice Production at Acidic Mineral Soil. Greener Journal of Agricultural Sciences. 2 (8) : 351-361. 2012

[15] Tisdale S. and W. Nelson. Soil Fertility and Fertilizer. Third edition New York. Macmillan Publishing. Co. Inc.694. 1975.
[16] Du, Y. X., Tao, K. Shi, and Y. Li. Degradation of lignite Model compounds by the action of white rot fungi. Mining Science and Technology J. 20 (1) :76-81. 2010.

[17] Muhammad Syahren Adzahar and Wong Nan Chong. . Extraction and chemical characteristics of nitro-humic acids from coals and composts. J. Trop. Agric, and Fd. Sc. 36 (2) :000-000. 2008.

[18] Martina KluIáková1 and Marcela Pavlíková. Lignitic humic acids as environmentally-friendly adsorbent for heavy metals. Hindawi Journal of Chemistry Article ID 7169019, 5 pages. 2017,

[19] Kim,, K.., Kim, J., Park, J., Kim, M., Owens, G., Youn, G., Lee, J. Immobilizer assisted management of metal-contaminated agricultural soils for safer food production. J. Environ. Manage. 102, 88 - 95. 2012.

[20] J. Asing, N.C. Wong and S. Lau. Optimization of extraction method and characterization of humic acid derived from coals and composts. J. Trop. Agric. and Fd. Sc. 37(2): 211-223. 2009.

[21] Ahmad, F. Effect of Clay Mineral and Clay-humic Acid Complexes on Availability and Fixation of Phosphate. Disertasi. University of Georgia. 221 p. 1989.

[22] Fiorentino, G., R. Spaccini, A. Piccolo. Separation of molekular constituens from a humic acid by solid-phase extraction following a transesterification reaction. Talanta 68, 1135-1142. 2006.

[23] Soegiman. Ilmu Tanah. Terjemahan dari The nature and Properties of Soils. Buckman and Brady. Bhatara Karya Aksara. 788 hal. 1982.

[24] Tan, K. H. Humic Matter in soil and the environtment. Principles and Controversies. Marcel Dekker, Inc. New York. 386 p. 2003. 